\title{
Bending strength of intra-ply/inter-ply hybrid thermoplastic composites
}

\author{
DOI: 10.35530/IT.070.01.1533
}

\section{Rezistența la încovoiere a compozitelor termoplastice hibride intra-strat/inter-strat}

Proprietățile de încovoiere ale compozitelor termoplastice hibride din fibră de carbon/E-glass/polipropilenă (PP) intra/inter-laminare au fost determinate și comparate cu cele ale compozitelor termoplastice nehibride din carbon/PP și E-glass/PP. Compozitele hibride și nehibride au fost fabricate utilizând prepreguri termoplastice țesute uni-direcționale din carbon/ PP, E-glass/PP și carbon/E-glass/PP. Fracțiile de fibre au afectat în mod semnificativ densitatea, rezistența la încovoiere, modulul de elasticitate și îndoirea-deformarea compozitelor hibride termoplastice. Rezistența la încovoiere și modulul compozitelor hibride termoplastice hibride au fost mai mari comparativ cu compozitele termoplastice nehibride. S-a observat că hibridizarea intra-laminară a provocat o deteriorare mai gravă după sarcina de încovoiere atât pe suprafață, cât și pe secțiunea transversală decât hibridizarea inter și intra/inter-laminară. Distribuția uniformă a fibrelor de carbon și E-glass în cadrul și între straturile compozitelor prin utilizarea hibridizării intra-laminare/interlaminare a rezultat într-un modul de elasticitate mai mare, de până la 65,1\% în comparație cu compozitele nehibride.

Cuvinte-cheie: compozite termoplastice, prereg unidirecțional, compozite hibride, rezistența la încovoiere, hibridizare

\section{Bending strength of intra-ply/inter-ply hybrid thermoplastic composites}

Bending properties of intra-ply, inter-ply and intra-ply/inter-ply Carbon/Electrical Glass (E-Glass)/polypropylene (PP) hybrid thermoplastic composites were determined and compared with those of non-hybrid Carbon/PP and E-Glass/PP thermoplastic composites. The hybrid and non-hybrid composites were manufactured by using the uni-directional woven carbon/PP, E-glass/PP and carbon/E-glass/PP thermoplastic prepregs. The fiber fractions significantly affected the density, bending-strength, bending-modulus and bending-deflection of hybrid thermoplastic composites. The bendingstrength and modulus of the hybrid thermoplastic composites were higher compared to non-hybrid thermoplastic composites. It is observed that the intra-ply hybridization caused a more catastrophic failure after bending load on both surface and cross-section than the inter-ply and intra-ply/inter-ply hybridization. The uniform distribution of Carbon and E-Glass fibers within and between the layers of composites by using intra-ply/inter-ply hybridization resulted as the higher bending modulus up to $65.1 \%$ compared to non-hybrid composites.

Keywords: thermoplastic composites, unidirectional prepreg, hybrid composites, bending strength, intra-ply hybridization

\section{INTRODUCTION}

Textile structural composites are widely used in various industries due to their high specific strengths, good fatigue and corrosion resistance [1]. Today, thermoplastic polymer based composites have a growing interest due to their easy forming and remolding ability in shorter process-times [2, 3]. Thermoplastic polymers differ from their thermoset counterpart primarily by their melt temperature being lower than their decomposition temperature, while thermoset polymers have melting temperatures higher than their decomposition temperature, meaning that they cannot be reshaped upon melting [4]. However, thermoplastic resins are about 500 to 1000 times more viscous than thermoset resins which restrict the infusion tendency of resins into fibers. A high-pressure requirement in the processing of thermoplastic composites is also considered as another restriction. Semi-crystalline thermoplastic polymers such as PEEK (polyether ether ketone), PPS (polyphenylene sulfide) and LCP (liquid-crystal polymers) are mainly used in aviation due to their mechanical and chemical resistance at relatively high temperatures. Some other thermoplastic polymers such as PP (polypropylene), ABS (acrylonitrile butadiene styrene) and PA (polyamide) find use in the automotive industry. PP is commonly used in the thermoplastic composite production due to its low-cost, high specific strength and re-usability [5-7].

Complex-material requirements in high-technical applications have led to increased use of hybrid materials since the non-hybrid materials do not have adequate performance [8]. Hybridization process can increase the mechanical properties of fiber reinforced composites and reduced its limitations [9]. By using proper material design, it is possible to achieve a balance between cost and performance. Types, orientation and arrangements of fibers mainly determine the properties of hybrid composites [8]. Hybrid composites can be classified as inter-ply and intra-ply. The inter-ply hybrid composite consists of different types of fiber plies bonded together in a matrix while in intra-ply hybrid composite, each ply consists of two or more types of fibers [10]. Thermoplastic prepregs are 
one of the most preferred materials in hybrid composite production. They can be stored at room temperature without any time restriction and converted to composites by using appropriate temperature and pressure [11-13]. Hybrid fabrics can be produced in the form of woven, knitted or braided fabric using commingled or wrapped yarns. In either commingled or wrapped yarns, the thermoplastic fibers are melted during the curing process and spread through reinforcing fibers by wetting to form polymeric matrix on solidification/cooling. Some process degradations such as filament breakages may occur in glass and carbon fibers of hybrid yarns which reduces the final composite performance [14]. Hybrid composite performance is dependent on the homogeneity of polymer fibers in yarn [15-19]. Co-weaving is another way to produce hybrid composites and described as weaving at least two different fibers together. Co-weaving can offer a wide variety of fiber material selections for designers and significant improvements in the cost-effectiveness of fabrication [20]. The most critical point in hybrid weaving is to have a uniform fiber distribution and using compatible fibers [21, 22].

Some detailed studies were performed by researchers about the mechanical and impact properties of hybrid composites. It was stated that the hybridization can be used to improve the flexural strength through appropriate fiber selection, geometry and placement $[23,24]$. Sorrentino et al. investigated the flexural and impact properties of hybrid thermoplastic composites based on polypropylene and glass fiber woven fabrics by using neat and modified PP films with coupling agent. It was stated that the capability to transfer loads from the matrix to the fibers increased by using coupling agent which improved the flexural modulus and flexural strength [25]. Xu et al. studied the bending behavior of unidirectional glass/PEEK composites manufactured by using wrapped yarns. Bending performances of the composites enhanced by the increase in molding temperature and molding time which also reduced the delamination based failures [26]. Process parameters have also effects on hybrid composite performance. Mechanical properties of hybrid composites molded directly at the process temperature without any preheating are lower than those of preheated molded composites [27]. Shekar et al. investigated the mechanical and thermal properties of glass/PEEK co-woven composites. It was stated that the uniformity in the distribution of resin between various layers of laminate during hybridization plays a major role and have a dominant impact on the mechanical properties of composites especially for aerospace applications [27]. Pandya et al. investigated inter-ply hybrid of E-glass/carbon/ epoxy composites. The tensile strengths of the composites where the glass fabric is on the outer layer and the carbon fabric is on the inner layer are higher than those of the composites in which carbon fabric is on the outer layer and the glass fabric is on the inner layer [10]. Zhang et al. produced glass/carbon/epoxy inter-ply hybrid composites. It was stated that when the carbon fabric is on the outer layer and the ratio of the carbon fabric of the hybrid composite is $50 \%$, the structures exhibit high bending strength. On the contrary, the hybrid composites in which the glass fabric is on the outer layer have higher compression strength [28]. The strain in individual fibers also affects the hybrid composite strength and using fibers which have compatible strains resulted as a high strength of hybrid composite [29]. The gain of percentage elongation for hybrid composite is significantly higher than the percentage loss in tensile strength [10]. In addition, hybrid composites have more delamination tendencies, especially between different fiber layers of inter-ply hybrid composites [30]. In most studies of the literature, commercially available fabrics and prepregs were used to manufacture hybrid composites and the thermoplastic fibers are used for toughness purpose in thermoset-based composites. The novelty of this work is investigating mechanical properties of both intra-ply/inter-ply hybrid thermoplastic composites which are produced by using unidirectional (UD) woven thermoplastic prepregs. These prepregs are woven at our laboratory. In the UD woven thermoplastic prepregs, both carbon and E-glass fibers are used as weft while polypropylene fibers are used as warp yarns. Using reinforcement and matrix fibers at warp and weft directions of the prepregs makes it possible to achieve the desired hybridization to withstand the exposed load and provides design flexibility to the composite endusers. This study aims to compare the bending properties of carbon/E-glass/PP intra-ply/inter-ply hybrid thermoplastic composites with non-hybrid carbon/PP and E-glass/PP thermoplastic composites. Bending behavior was studied as considering the bending strength, bending modulus, bending strain and their normalized forms based on both the measured density and fiber volume fraction as specific bending strength, specific bending modulus and specific bending strain. The failures of composites after the bending load were evaluated with optical microscope and SEM (Scanning Electron Microscope) views.

\section{EXPERIMENTAL PART}

\section{UD woven thermoplastic prepregs and hybrid thermoplastic composites}

Three types of UD thermoplastic prepregs were woven in a manual weaving loom: carbon/PP (PP/C), E-glass/PP (PP/G) and carbon/E-glass/PP (PP/H). BCF (Bulk Continuous Filament) PP fibers (made by Eruslu Textile, Turkey) were used as warp $\left(0^{\circ}\right)$ while carbon fiber (Aksa, Turkey) and E-glass fiber (Cam Elyaf A.S., Turkey) were used as weft $\left(90^{\circ}\right)$. These developed prepregs are defined as the UD woven thermoplastic prepregs since the warp fiber of PP melts at temperature $\left(205^{\circ} \mathrm{C}\right)$ during consolidation process and acts as a matrix. Specifications of the fibers according to producer companies are given in table 1.

$\mathrm{PP} / \mathrm{C}, \mathrm{PP} / \mathrm{G}$ and $\mathrm{PP} / \mathrm{H}$ UD woven thermoplastic prepregs were in a plain weave pattern due to 


\begin{tabular}{|l|c|c|c|c|c|c|c|}
\hline \multicolumn{7}{|c|}{ SPECIFICATIONS OF THE FIBRES USED IN HYBRID WOVEN THERMOPLASTIC PREPREGS } \\
\hline Fibre type & $\begin{array}{c}\text { Measured fibre } \\
\text { diameter }(\boldsymbol{\mu m})\end{array}$ & $\begin{array}{c}\text { Fiber } \\
\text { density } \\
\left(\mathbf{g} / \mathbf{c m}^{\mathbf{3}}\right)\end{array}$ & $\begin{array}{c}\text { Tensile } \\
\text { strength } \\
(\mathbf{M P a})\end{array}$ & $\begin{array}{c}\text { Tensile } \\
\text { modulus } \\
(\mathbf{G P a})\end{array}$ & $\begin{array}{c}\text { Elongation } \\
(\%)\end{array}$ & $\begin{array}{c}\text { Melting } \\
\text { point } \\
\left({ }^{\circ} \mathbf{C}\right)\end{array}$ & $\begin{array}{c}\text { Linear } \\
\text { density } \\
\text { of yarn }\end{array}$ \\
\hline Carbon & 6.17 & 1.78 & 4200 & 240 & 1.8 & $>1200$ & $3 K^{*}$ \\
\hline E-Glass & 18.34 & 2.57 & 2306 & 81.5 & 2.97 & 840 & 410 tex \\
\hline Polypropylene & - & 0.90 & 35 & 14 & 30 & 175 & 150 tex \\
\hline
\end{tabular}

${ }^{*} \mathrm{~K}=1000$ filament in TOW.

Table 2

SPECIFICATIONS OF HYBRID WOVEN THERMOPLASTIC PREPREGS

\begin{tabular}{|c|c|c|c|c|c|c|c|c|c|c|}
\hline \multirow{2}{*}{$\begin{array}{c}\text { Prepreg } \\
\text { type }\end{array}$} & \multirow{2}{*}{$\begin{array}{c}\text { Weave } \\
\text { type }\end{array}$} & \multicolumn{2}{|c|}{ Yarn sets } & \multicolumn{2}{|c|}{$\begin{array}{l}\text { Density } \\
\text { (per cm) }\end{array}$} & \multirow{2}{*}{$\begin{array}{l}\text { Weight } \\
\left(\mathrm{g} / \mathrm{m}^{2}\right)\end{array}$} & \multicolumn{2}{|c|}{$\begin{array}{c}\text { Crimp } \\
(\%)\end{array}$} & \multirow{2}{*}{$\begin{array}{l}\text { Thickness } \\
\text { (mm) }\end{array}$} & \multirow{2}{*}{$\begin{array}{c}\text { Cover } \\
\text { factor } \\
(\%)\end{array}$} \\
\hline & & Warp & Weft & Warp & Weft & & Warp & Weft & & \\
\hline $\mathrm{PP} / \mathrm{C}$ & Plain & PP & 6 Carbon & 4 & 4.5 & 794 & 5.0 & 2.0 & $1.35 \pm 0.02$ & 99.72 \\
\hline$P P / G$ & Plain & PP & 6 E-Glass & 4 & 5.5 & 1278 & 16.2 & 1.0 & $1.54 \pm 0.02$ & 98.30 \\
\hline $\mathrm{PP} / \mathrm{H}$ & Plain & PP & $\begin{array}{l}6 \text { E-Glass/ } \\
3 \text { Carbon }\end{array}$ & 4 & 5.5 & 1027 & 8.8 & $1.0 / 2.0$ & $1.46 \pm 0.02$ & 97.17 \\
\hline
\end{tabular}

Table 3

\begin{tabular}{|c|c|c|c|c|}
\hline \multicolumn{5}{|c|}{ DESCRIPTIONS OF THE DEVELOPED HYBRID THERMOPLASTIC COMPOSITES } \\
\hline Label & Hybridization & Layers & Orientation & Order of layers* \\
\hline PP/CC & non-hybrid & 4 layers & {$\left[90^{\circ} / 0^{\circ}\right]_{2}$} & $1: 90^{\circ}(\mathrm{PP} / \mathrm{C}), 2: 0^{\circ}(\mathrm{PP} / \mathrm{C}), 3: 90^{\circ}(\mathrm{PP} / \mathrm{C}), 4: 0^{\circ}(\mathrm{PP} / \mathrm{C})$ \\
\hline PP/GC & non-hybrid & 4 layers & {$\left[90^{\circ} / 0^{\circ}\right]_{2}$} & $1: 90^{\circ}(\mathrm{PP} / \mathrm{G}), 2: 0^{\circ}(\mathrm{PP} / \mathrm{G}), 3: 90^{\circ}(\mathrm{PP} / \mathrm{G}), 4: 0^{\circ}(\mathrm{PP} / \mathrm{G})$ \\
\hline PP/HC & intra-ply & 4 layers & {$\left[90^{\circ} / 0^{\circ}\right]_{2}$} & $1: 90^{\circ}(\mathrm{PP} / \mathrm{H}), 2: 0^{\circ}(\mathrm{PP} / \mathrm{H}), 3: 90^{\circ}(\mathrm{PP} / \mathrm{H}), 4: 0^{\circ}(\mathrm{PP} / \mathrm{H})$ \\
\hline PP/IL1 & intra-ply/inter-ply & 4 layers & {$\left[90^{\circ} / 0^{\circ}\right]_{2}$} & $1: 90^{\circ}(\mathrm{PP} / \mathrm{C}), 2: 0^{\circ}(\mathrm{PP} / \mathrm{H}), 3: 90^{\circ}(\mathrm{PP} / \mathrm{C}), 4: 0^{\circ}(\mathrm{PP} / \mathrm{H})$ \\
\hline PP/IL2 & intra-ply/inter-ply & 4 layers & {$\left[90^{\circ} / 0^{\circ}\right]_{2}$} & $1: 90^{\circ}(\mathrm{PP} / \mathrm{G}), 2: 0^{\circ}(\mathrm{PP} / \mathrm{H}), 3: 90^{\circ}(\mathrm{PP} / \mathrm{G}), 4: 0^{\circ}(\mathrm{PP} / \mathrm{H})$ \\
\hline PP/IL3 & inter-ply & 4 layers & {$\left[90^{\circ} / 0^{\circ}\right]_{2}$} & $1: 90^{\circ}(\mathrm{PP} / \mathrm{C}), 2: 0^{\circ}(\mathrm{PP} / \mathrm{G}), 3: 90^{\circ}(\mathrm{PP} / \mathrm{C}), 4: 0^{\circ}(\mathrm{PP} / \mathrm{G})$ \\
\hline
\end{tabular}

* 1: top layer, 4: bottom layer.

achieve a uniform distribution of polypropylene fibers among the carbon/E-glass fibers with more interlacement. Specifications of PP/C, PP/G and PP/H UD woven thermoplastic prepregs are given in table 2 . The thickness of UD woven thermoplastic prepregs was measured using portable thickness gauge (SDL Atlas, J200) according to ISO 5084 standard [31]. Crimp and weights of prepregs were measured according to ISO $7211-3$ and ISO 6348 test standards, respectively [32, 33].

As seen in table 2, weights of PP/C, PP/G and PP/H were 794, 1278 and $1027 \mathrm{~g} / \mathrm{m}^{2}$, respectively. Weft crimps of UD woven thermoplastic prepregs were quite lower than the warp crimps since the stiffer structure of carbon and E-glass fibers compare to bulky PP fibers. UD woven thermoplastic prepregs had the similar thicknesses. By using these PP/C, PP/G and PP/H UD woven thermoplastic prepregs, various non-hybrid, inter-ply hybrid, intra-ply hybrid and intra-ply/inter-ply hybrid composites (six types) were developed as described in table 3.
Hot-press (Wermac ${ }^{\circledR}-\mathrm{H} 501$, Turkey) was used to consolidate the layered prepregs. Teflon films were used on both top and bottom to prevent any sticking of composites with hot plates of press during consolidation. Prepregs were placed on hot-press at $50^{\circ} \mathrm{C}$. Then, the temperature was reached to $205^{\circ} \mathrm{C}$ in 20 minutes. The process was continued for 40 minutes at this temperature and then cooled down to room temperature. The pressure was fixed to 5.5 bars during all the process. Figure 1 shows the microscopic views of thermoplastic prepregs (figure 1,a) and composites (figure 1,b). Density measurements of composites were conducted by ASTM D792-13 [34]. Density measurement was performed by using a density meter (Precisa ${ }^{\circledR}$, XP205) in which the weight of specimen was measured in air at first and then in distilled water at a room temperature. The composite fiber fraction was determined by ASTM D3171-15 [35]. The weight-based fiber fractions of carbon, E-glass and PP were separately determined and the total fiber fractions were calculated as both weight and volume based. 


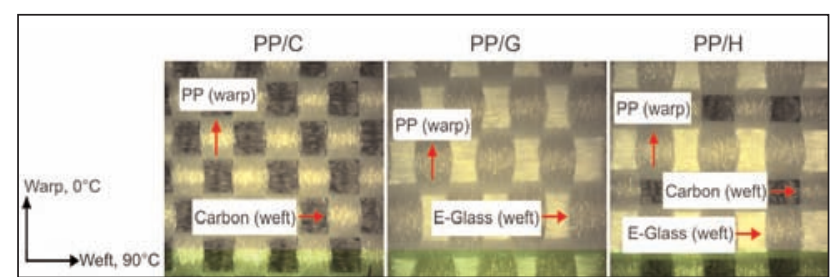

a

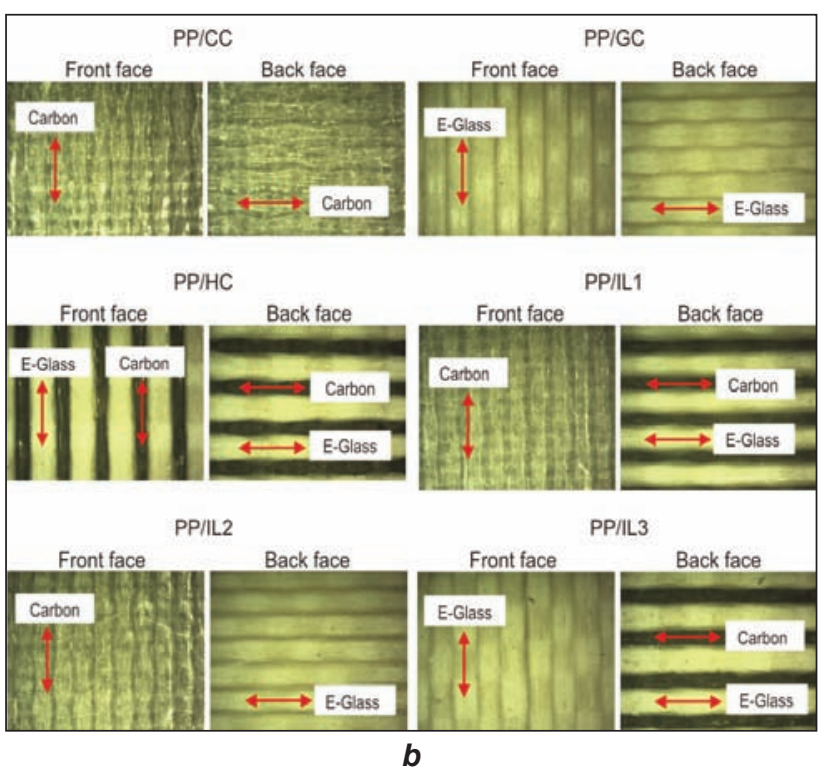

Fig. 1. Microscopic views of thermoplastic prepregs (a) and composites (b)

\section{Bending strength test}

Bending strengths of hybrid thermoplastic composites were determined according to ASTM D790 by using 3-point bending test method [36]. Schematic view (figure $2, a$ ) and photos (figure 2,b) of 3-point bending test are shown in figure 2. The bending strength tests of the hybrid thermoplastic composites were performed on a Hounsfield H5KS (UK) tester. Test speed was $1.3 \mathrm{~mm} / \mathrm{min}$. The support span length to thickness ratio (L/d) was used as 16/1. The bending load was applied on normal to top-layer of hybrid thermoplastic composites. The dimension of the test specimen was $25 \mathrm{~mm} \times 80 \mathrm{~mm}$. Support span length was $50 \mathrm{~mm}$. Bending strength test was performed on four specimens for each type of samples. The bending strength (1), modulus (2) and strain (3) of hybrid thermoplastic composites were calculated according to the formulations of ASTM D790-90 which are given below:

$$
\begin{gathered}
S=3 P L / 2 b d^{2} \\
E=L^{3} m / 4 b d^{3} \\
\varepsilon=\left(I_{1}-I_{0}\right) / I_{0}=\Delta / / I_{0}
\end{gathered}
$$

where: $S$ is the stress in the outer fibers at mid-span $\left(\mathrm{N} / \mathrm{m}^{2}\right), P$ - the load at a given point on the loaddeflection curve $(\mathrm{N}), L$ - the support span $(\mathrm{m}), b$ - the width of beam tested $(\mathrm{m}), d$ - the depth of beam tested $(m), E-$ the modulus of elasticity in bending $\left(\mathrm{N} / \mathrm{m}^{2}\right), m$ - the slope of the tangent to the initial straight-line portion of the load-deflection curve $(\mathrm{N} / \mathrm{m})$

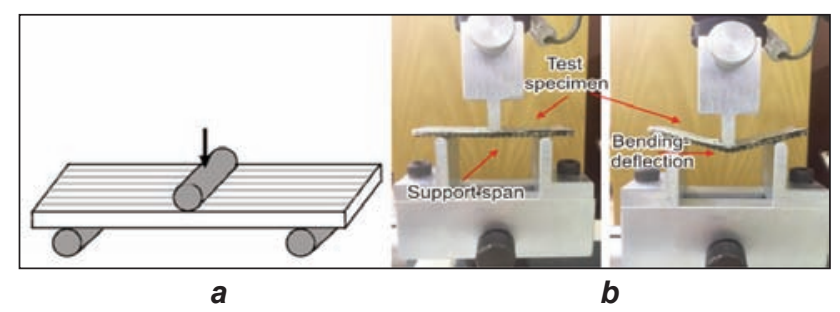

Fig. 2. Schematic view (a) and photos (b) of 3-point bending test

of deflection, $\varepsilon$ - the bending deflection (\%), $\Delta l-$ the elongation $(\mathrm{m})$ and $I_{0}-$ the initial length $(\mathrm{m})$.

The specific-bending strength (4), modulus (5) and deflection (6) were also calculated to evaluate the test results in normalized form based on both the measured density [37] and fiber volume fraction $\left(V_{f}\right)$.

$$
\begin{aligned}
& S_{\text {spec }}=s / \rho, S_{\text {spec }}=S / V_{f} \\
& E_{\text {spec }}=E / \rho, E_{\text {spec }}=E / V_{f} \\
& \varepsilon_{\text {spec }}=\varepsilon / \rho, \varepsilon_{\text {spec }}=\varepsilon / V_{f}
\end{aligned}
$$

where: $\rho$ is the measured-density of hybrid composites $\left(\mathrm{gcm}^{-3}\right), V_{f}$ - the fiber volume fraction, $S_{\text {spec }}-$ the specific-bending strength, $E_{\text {spec }}-$ the specificbending modulus and $\varepsilon_{\text {spec }}$ - the specific-bending deflection. Moreover, the surface and cross-sectional failures of thermoplastic hybrid composites after the bending strength test were examined by using an optical microscope (BAB Bs200Doc, Turkey) and SEM (ZEISS EVO ${ }^{\circledR}$ LS10).

\section{RESULTS AND DISCUSSION}

\section{Density and fiber fraction test results}

Table 4 shows the density and fiber fraction results of the hybrid thermoplastic composites. The thickness values of hybrid thermoplastic composites were varied from 2.65 to $3.26 \mathrm{~mm}$ depending on the used prepreg types. Because of the higher fiber density of E-glass compare to carbon, PP/GC had the highest composite density as $1.87 \mathrm{~g} / \mathrm{cm}^{3}$ and followed by the PP/IL2, PP/HC and PP/IL3 hybrid composites depending on the fiber fractions. The lowest composite density was obtained from PP/CC since the lower density of carbon fiber compare to that of E-glass fiber. The densities of hybrid thermoplastic composites were affected by the used fiber ratios. The composite density increased by the increase in E-glass fiber ratio. Generally, the weight-based total fiber fractions were quite high in all types of hybrid composites. The volume-based total fiber fractions were varied depending on the ratios of Carbon and E-glass fibers used. PP/GC had the highest weight-based and volume-based total fiber fractions because of the higher yarn linear density and fiber density E-glass. Fiber fractions can be varied by the constructional arrangements of weaving as using different warp and weft densities, weaving patterns and yarn linear densities. Thus, it is possible to weave prepregs related 
THE DENSITY AND FIBER FRACTION RESULTS OF THE HYBRID THERMOPLASTIC COMPOSITES

\begin{tabular}{|c|c|c|c|c|c|c|c|}
\hline \multirow{3}{*}{ Label } & \multirow{3}{*}{$\begin{array}{l}\text { Thickness } \\
\text { (mm) }\end{array}$} & \multirow{3}{*}{$\begin{array}{l}\text { Density } \\
\left(\mathrm{gcm}^{-3}\right)\end{array}$} & \multicolumn{5}{|c|}{ Fiber fraction (\%) } \\
\hline & & & \multicolumn{4}{|c|}{ Weight-based } & \multirow{2}{*}{$\begin{array}{c}\text { Volume-based } \\
\left(V_{f}\right)\end{array}$} \\
\hline & & & Carbon & E-Glass & PP & Total & \\
\hline $\mathrm{PP} / \mathrm{CC}$ & $3.11 \pm 0.02$ & $1.32 \pm 0.02$ & 84.40 & - & 15.60 & 84.40 & 62.59 \\
\hline PP/GC & $3.26 \pm 0.09$ & $1.87 \pm 0.02$ & - & 89.94 & 10.06 & 89.94 & 65.44 \\
\hline $\mathrm{PP} / \mathrm{HC}$ & $3.15 \pm 0.03$ & $1.62 \pm 0.04$ & 17.72 & 69.38 & 12.90 & 87.10 & 52.92 \\
\hline PP/IL1 & $2.65 \pm 0.04$ & $1.50 \pm 0.07$ & 46.79 & 39.14 & 14.07 & 85.93 & 53.86 \\
\hline PP/IL2 & $2.98 \pm 0.03$ & $1.70 \pm 0.01$ & 7.90 & 80.78 & 11.32 & 88.68 & 46.34 \\
\hline PP/IL3 & $3.16 \pm 0.06$ & $1.61 \pm 0.02$ & 32.34 & 55.48 & 12.18 & 87.82 & 61.81 \\
\hline
\end{tabular}

to load to be exposed and end-use areas of composites which provide design flexibility.

\section{Bending strength test results}

The bending strength test results of hybrid thermoplastic composites are presented in table 5 and table 6 . Figure 3 shows the load-deflection (figure $3, a$ ) and strength-deflection (figure $3, b$ ) curves of hybrid thermoplastic composites. As seen in figure 2, the loaddeflection curves of all hybrid and non-hybrid composites executed ductile-material behavior as expected due to PP used as matrix. The carbon fibers are used for their high strength in hybridization. The glass fibers have higher strain-to-failure in tension than that of carbon fibers which provides higher strength to hybrid composites. PP/CC composites are generally stiffer than PP/GC and PP/HC composites because of the brittle behavior of carbon fibers. PP/HC intraply hybrid composites are more flexible compared to

Table 5

\begin{tabular}{|c|c|c|c|}
\hline \multicolumn{4}{|c|}{$\begin{array}{c}\text { THE BENDING STRENGTH TEST RESULTS OF THE } \\
\text { HYBRID THERMOPLASTIC COMPOSITES }\end{array}$} \\
\hline Label & $\begin{array}{c}\text { Strength } \\
\text { (MPa) }\end{array}$ & $\begin{array}{c}\text { Modulus } \\
\text { (GPa) }\end{array}$ & $\begin{array}{c}\text { Deflection } \\
(\%)\end{array}$ \\
\hline PP/CC & $19.76 \pm 0.28$ & $2.95 \pm 0.22$ & $75.90 \pm 6.94$ \\
\hline PP/GC & $20.59 \pm 0.95$ & $1.30 \pm 0.36$ & $134.63 \pm 6.40$ \\
\hline PP/HC & $21.08 \pm 1.41$ & $2.34 \pm 0.19$ & $85.25 \pm 4.61$ \\
\hline PP/IL1 & $24.51 \pm 2.64$ & $3.73 \pm 1.16$ & $56.00 \pm 1.59$ \\
\hline PP/IL2 & $21.85 \pm 1.63$ & $3.66 \pm 0.16$ & $41.51 \pm 6.35$ \\
\hline PP/IL3 & $19.87 \pm 2.62$ & $1.93 \pm 0.52$ & $99.18 \pm 8.68$ \\
\hline
\end{tabular}

non-hybrid composites since the contribution of higher strain of glass fibers. In addition, intra-ply/inter-ply hybrid PP/IL1 composites behaved as a stiff material according to the load-deflection curves in which they showed a sharp decrease of breaking-point. The breaking loads of hybrid and non-hybrid composites were varied between from 62.50 to $88.87 \mathrm{~N}$. Intra-ply hybrid PP/HC composite showed the highest breaking load since the uniform distribution of carbon and E-glass fibers within the composite layers. Figures 3, 4 and 5 show the bending strength/specific-bending strength, the bending-modulus/specific-bending modulus and the bending-deflection/specific-bending deflection results of hybrid thermoplastic composites, respectively.

\section{Bending strength}

As presented in tables 5 and 6 and figures 4 , the bending strengths of hybrid thermoplastic composites were varied from 19.76 to $24.51 \mathrm{MPa}$ while the specific-bending strengths of hybrid thermoplastic composites were varied from 11.01 to $16.34 \mathrm{MPa} /$ $\mathrm{gcm}^{-3}$ and from 0.32 to $0.47 \mathrm{MPa} / \mathrm{V}_{\mathrm{f}}$. PP/IL1 intraply/inter-ply hybrid thermoplastic composite showed the highest bending-strength and followed by PP/IL2 which was also an intra-ply/inter-ply hybrid composite. PP/CC had the lowest bending-strength while the specific-bending-strength of PP/CC was higher than those of PP/HC, PP/IL2, PP/IL3 and PP/GC composites. The structure and properties of the fiber-matrix interface is crucial to the mechanical behavior of composite materials [38]. The low bending properties of PP/CC composites may be attributed to weak

THE SPECIFIC BENDING STRENGTH TEST RESULTS OF THE HYBRID THERMOPLASTIC COMPOSITES

\begin{tabular}{|c|c|c|c|c|c|c|}
\hline \multirow{2}{*}{ Label } & \multicolumn{2}{|c|}{ Specific strength } & \multicolumn{2}{|c|}{ Specific modulus } & \multicolumn{2}{|c|}{ Specific deflection } \\
\hline & $\left(\mathrm{MPa} / \mathrm{gcm}^{-3}\right)$ & $\left(\mathrm{MPa} / \mathrm{V}_{\mathrm{f}}\right)$ & $\left(\mathrm{GPa} / \mathrm{gcm}^{-3}\right)$ & $\left(G P a / V_{f}\right)$ & $\left(\% / \mathrm{gcm}^{-3}\right)$ & $\left(\% / V_{f}\right)$ \\
\hline PP/CC & 14.97 & 0.32 & 2.23 & 0.05 & 57.50 & 1.21 \\
\hline PP/GC & 11.01 & 0.31 & 0.70 & 0.02 & 71.99 & 2.06 \\
\hline PP/HC & 13.01 & 0.46 & 1.44 & 0.04 & 52.62 & 1.61 \\
\hline PP/IL1 & 16.34 & 0.39 & 2.48 & 0.07 & 37.33 & 1.04 \\
\hline PP/IL2 & 12.62 & 0.47 & 2.15 & 0.08 & 24.41 & 0.90 \\
\hline PP/IL3 & 12.26 & 0.32 & 1.19 & 0.03 & 61.22 & 1.60 \\
\hline
\end{tabular}



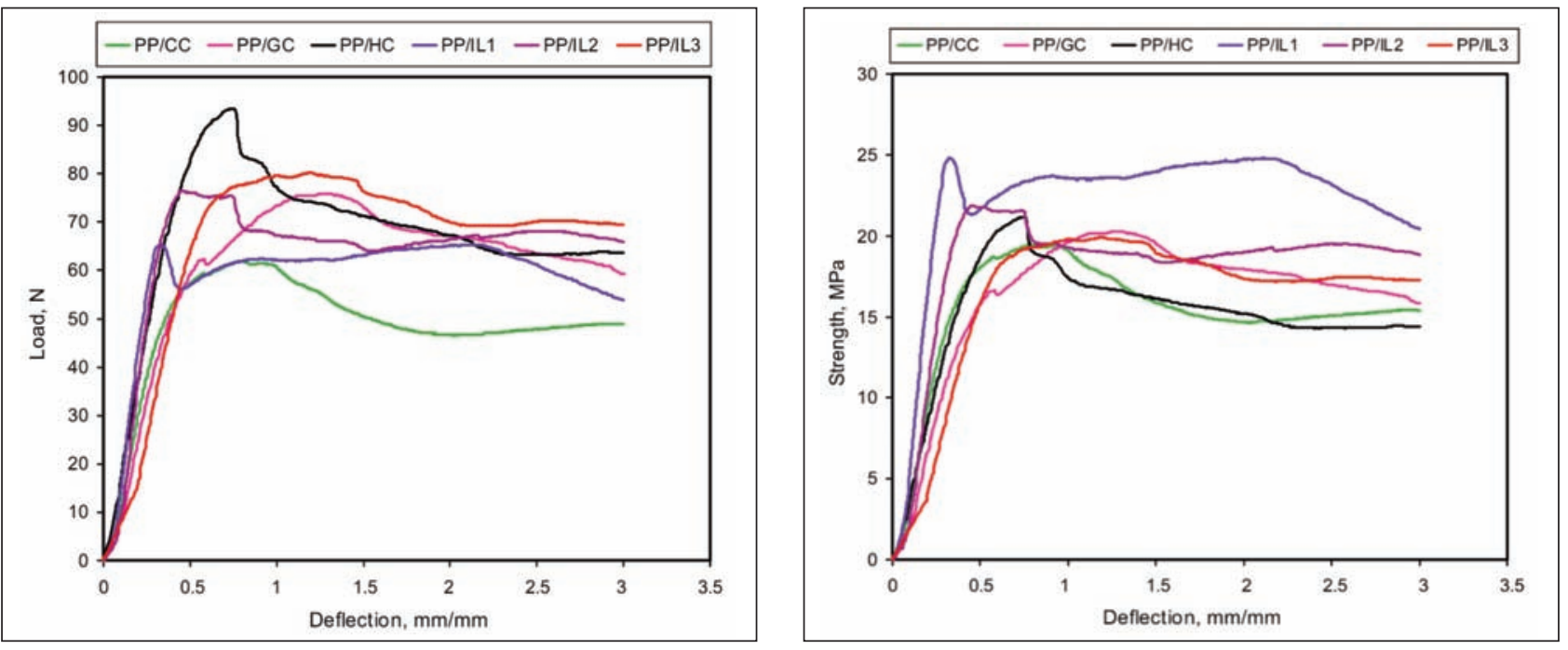

a

b

Fig. 3. Load-deflection (a) and strength-deflection (b) curves of composites

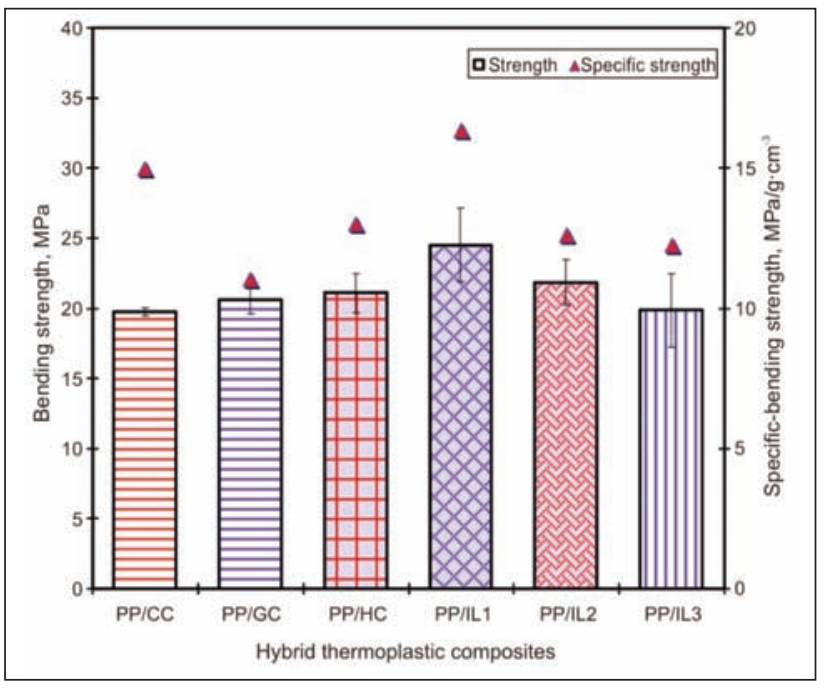

a

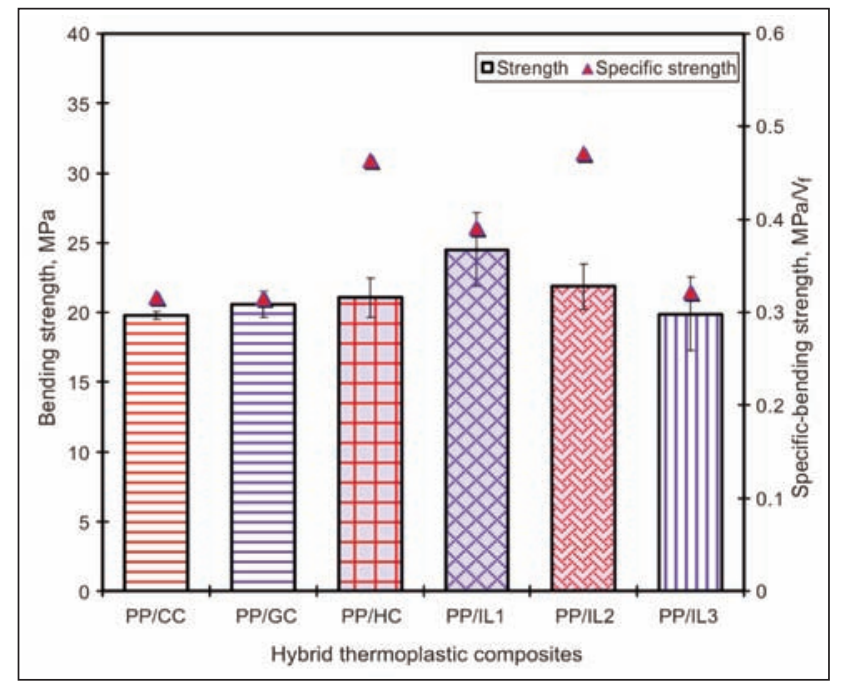

b

Fig. 4. The bending-strength and specific-bending strength of hybrid thermoplastic composites, density based specific-bending-strength (a), volume fraction based specific-bending-strength (b)

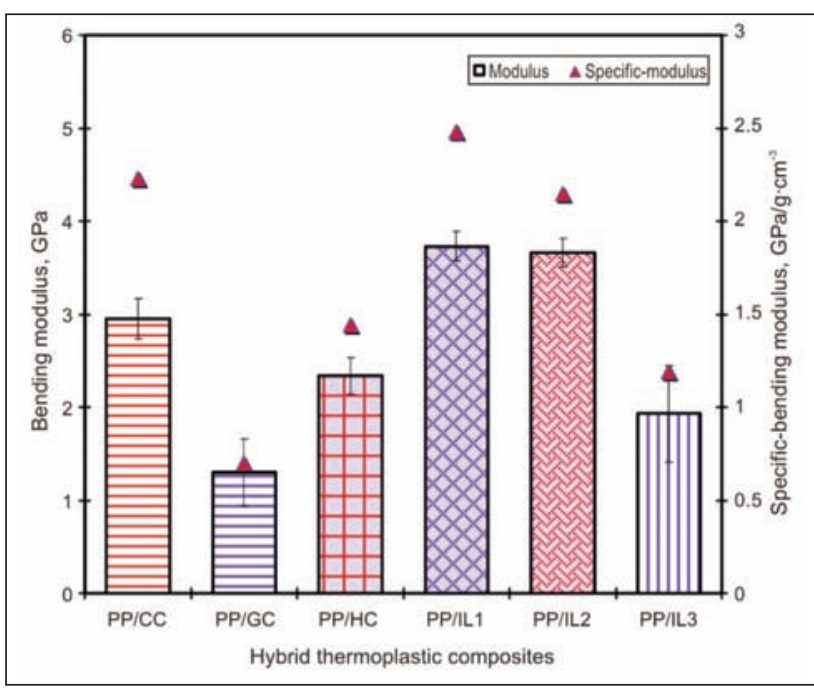

a

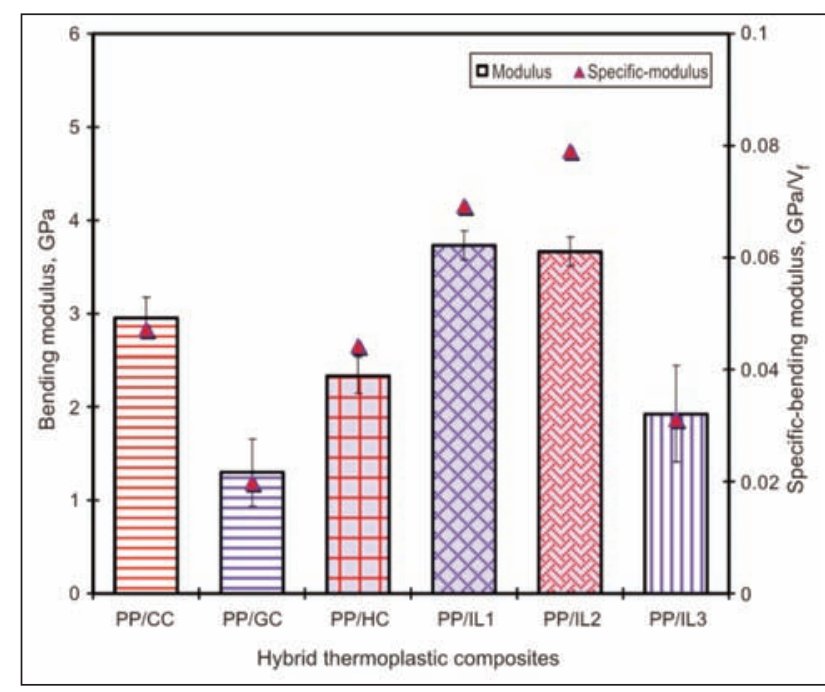

b

Fig. 5. The bending-modulus and specific-bending modulus of hybrid thermoplastic composites, density based specific-bending-modulus (a), volume fraction based specific-bending-modulus (b) 


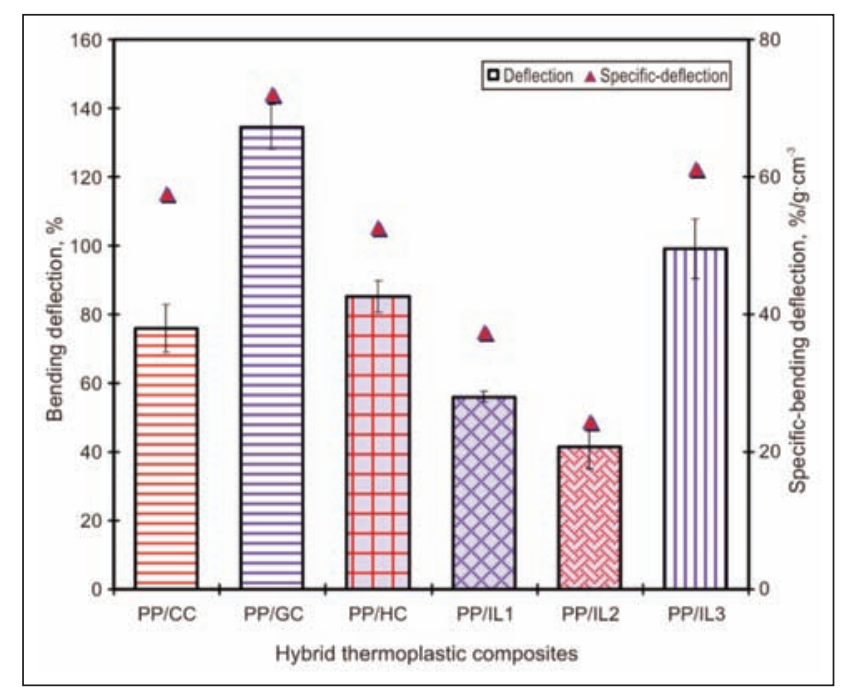

a

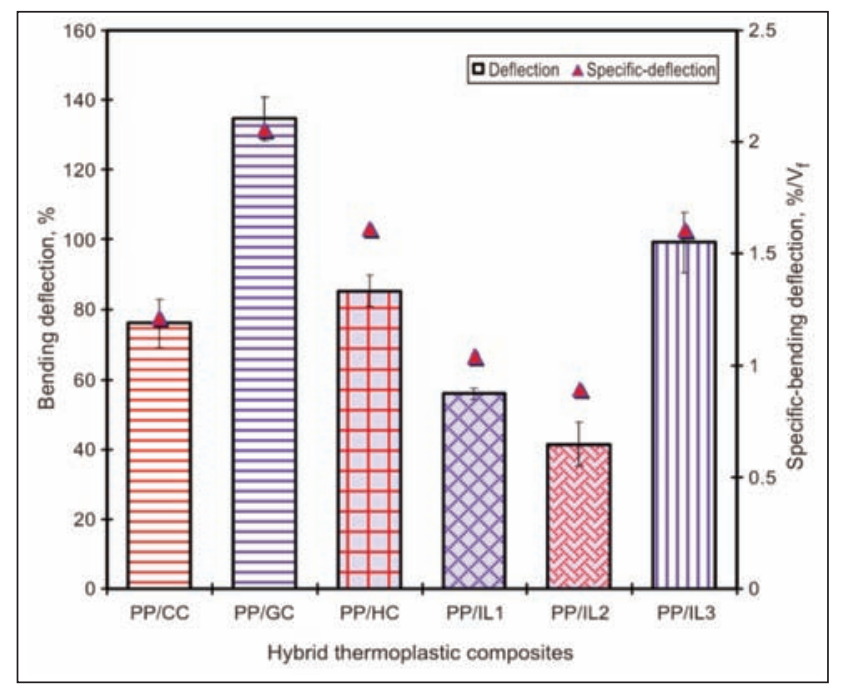

b

Fig. 6. The bending-deflection and specific-bending deflection of hybrid thermoplastic composites, density based specific-bending-deflection (a), volume fraction based specific-bending-deflection (b)

interface properties of carbon/PP during consolidation process. PP/IL1 and PP/IL2 showed the higher density based and volume fraction based specificbending-strengths. By using intra-ply/inter-ply hybridization (PP/IL1) increased the bending strength as $19.4 \%$ and $17.2 \%$ compared to non-hybrid PP/CC and PP/GC composites, respectively. It could be caused by the constraint from the intra-ply and interply E-glass fibers that prevent carbon fiber breakages and formed a considerable hybridization effect due to the delay in failure of the carbon fibers [39]. The uniform distribution of carbon and E-glass fibers within and between the layers the composite structure was also increased the bending strength of composites. However, using different types of reinforcement fibers as carbon and E-glass as layered forms caused an inter-layer delamination under bending load. It was found that the using intra-ply/inter-ply hybridization was a more effective method to obtain higher bending strengths than inter-ply or intra-ply hybridization. The bending-strength of hybrid thermoplastic composites was significantly affected by the intra-ply, inter-ply or intra-ply/inter-ply hybridization. In addition, bending strength is mainly dependent on the fiber-content and fiber-properties of the composites which confirms the synergic effect of hybridization.

\section{Bending modulus}

As presented in tables 5 and 6 and figure 5 , the bending-modulus of hybrid thermoplastic prepregs was varied from 1.30 to $3.73 \mathrm{GPa}$ while the specific-bending modulus of hybrid thermoplastic composites was varied from 0.70 to $2.48 \mathrm{GPa} / \mathrm{gcm}^{-3}$ and from 0.02 to $0.08 \mathrm{GPa} / \mathrm{V}_{\mathrm{f}}$. The bending-modulus of hybrid thermoplastic composites was generally compatible with their specific-bending modulus. The bending-modulus and specific bending-modulus values of PP/IL1 and PP/IL2 were similar and higher than those of PP/CC, PP/HC, PP/IL3 and PP/GC composites. The fiber fractions affected the bending-modulus of composites. It could be concluded that the bending-modulus of hybrid composites generally increased by the increase in carbon fiber fraction because of the higher fiber modulus of carbon compare to E-glass. However, non-hybrid PP/CC showed low bending modulus because of the weak interface properties of carbon/PP during consolidation process.

The carbon fibers are used for their high strength in hybridization. The glass fibers have higher strain-tofailure in tension than that of carbon fibers which provides higher strength to hybrid composites. The intraply, inter-ply and intra-ply/inter-ply hybridizations increased the bending modulus of composites by combining the unique specific modulus of carbon and strain of E-glass fibers. The uniform distribution of carbon and E-glass fibers within and between the layers of composites by using intra-ply/inter-ply hybridization resulted in the higher bending modulus. Since the carbon and E-glass fibers have different interface properties with PP during consolidation process in which the interface properties of glass/PP are stronger than that of carbon/PP, it was also important to obtain a balanced Carbon/E-Glass fiber ratio in intra-ply/inter-ply hybridization [38]. PP/IL1 exhibited this balance and thus it had the highest bendingmodulus and specific-bending-modulus. PP/IL1 and PP/IL2 showed the higher and density based and volume fraction based specific-bending-modulus. By using both intra-ply/inter-ply hybridization (PP/IL1) increased the bending-modulus as $20.9 \%$ and $65.1 \%$ compared to non-hybrid PP/CC and PP/GC composites, respectively. The specific-bending modulus of PP/IL1 was higher $10.1 \%$ and $71.7 \%$ than those of non-hybrid PP/CC and PP/GC composites, respectively. The bending-modulus of hybrid thermoplastic composites was significantly improved by the intraply, inter-ply or intra-ply/inter-ply hybridization. 


\section{Bending deflection}

As presented in tables 5 and 6 and figure 6 , the bending-deflections of hybrid thermoplastic prepregs were varied from $41.51 \%$ to $134.63 \%$ while the specificbending deflections of hybrid thermoplastic composites were varied from 24.41 to $71.99 \% / \mathrm{gcm}^{-3}$ and from 0.90 and $2.06 \% / V_{f}$. Generally, non-hybrid and hybrid thermoplastic composites exhibited a quite ductile behavior which means these composite structures absorb energy elastically. PP/CC composites are generally stiffer than PP/GC and PP/HC composites because of the brittle behavior of carbon fibers. $\mathrm{PP} / \mathrm{HC}$ intra-ply hybrid composites are more flexible compared to non-hybrid composites since the contribution of higher strain of glass fibers. The non-hybrid PP/GC composite showed almost 2-times higher bending deflection compare to non-hybrid PP/CC composite due to the high fiber strain of E-glass. Intra-ply/inter-ply hybrid PP/IL1 and PP/IL2 composites which had the highest bending-modulus showed the lowest bending-deflection/specific-bending-deflection as expected. It can be concluded that the ductility of hybrid thermoplastic composites decreased by the increase in carbon fiber ratio of the composite. The bending-deflection of hybrid thermoplastic composites was significantly decreased by the intra-ply, interply or intra-ply/inter-ply hybridization.

\section{Failure of hybrid thermoplastic composites}

Figure 7 shows the surface and cross-sectional microscopic failure analyses of hybrid thermoplastic composites. As seen in figure 7 , non-hybrid and hybrid thermoplastic composites generally showed a layer delamination and fiber breakages on their cross-section and fiber undulations on their front faces. The flexure load caused a compression based failure on the top surface and a tension based failure at the bottom surface [40]. The non-hybrid PP/CC composite had an intensive fiber undulation on its front face. This was due to the weak fiber/matrix interface properties of carbon and PP [41]. Fiber breakages, matrix cracks and some local delamination were observed on cross-sectional views. There was an insignificant failure on the back face of PP/CC. A similar tendency of failure was observed for non-hybrid PP/GC composite. However, the fiber undulations on the front face were fewer than that of PP/CC. It could be concluded that the fiber/matrix interface of E-glass/PP was stronger than that of carbon/PP. The intra-ply hybrid PP/HC composite showed an intense fiber undulation on its front face. Moreover, some of the fiber-matrix delaminations were observed on the back face after bending load. This was due to different adhesion properties of carbon/PP and E-glass/ PP fibers during consolidation process which caused by the different surface and heat-transfer properties of carbon and E-glass fibers. A wide layer delamination was also observed on the cross-section of PP/HC besides the fiber breakage. The intra-ply hybrid PP/HC exhibited a more catastrophic failure than non-hybrid PP/CC and PP/GC composites on

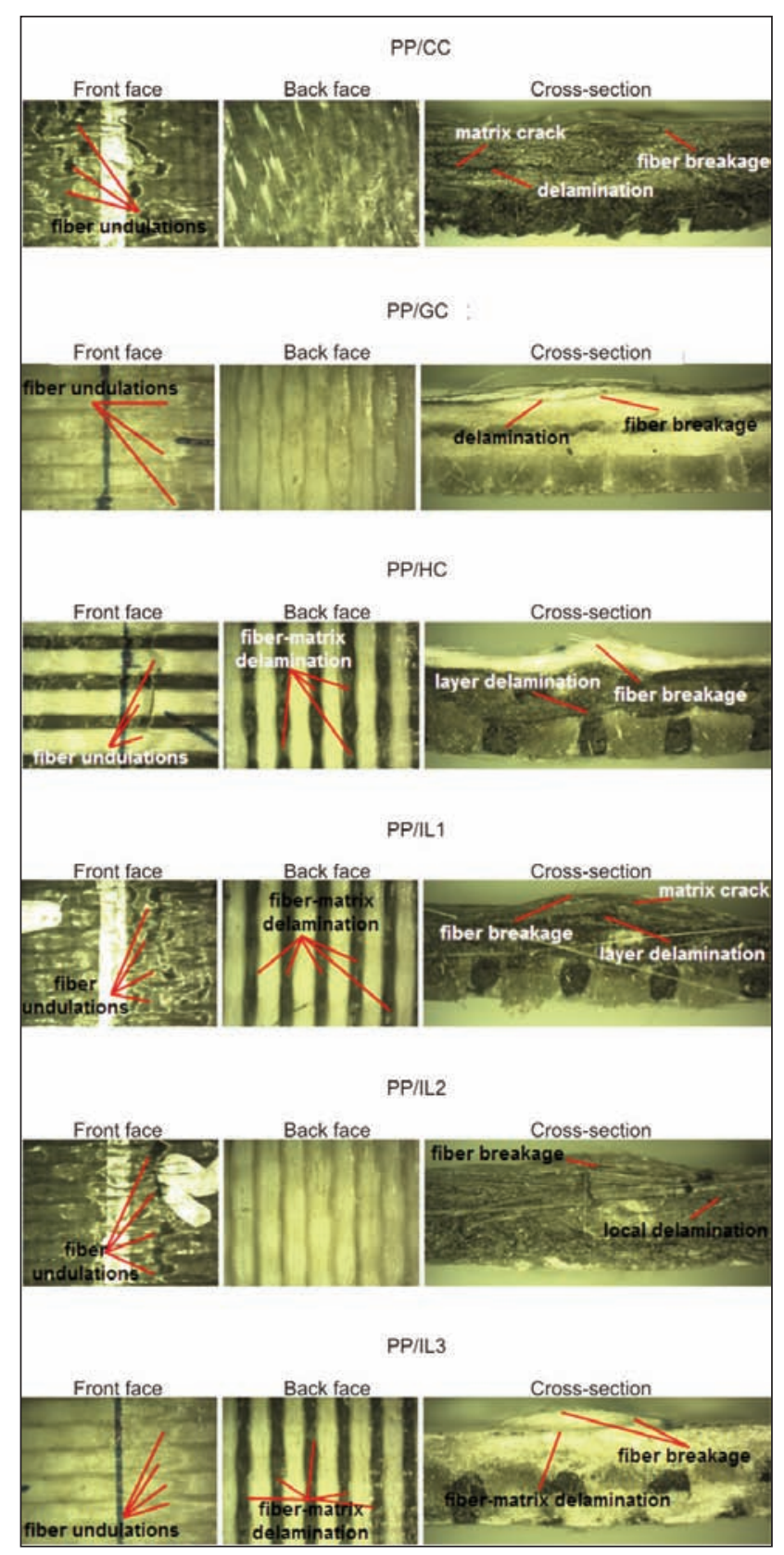

Fig. 7. The surface and cross-sectional microscopic failure analyses of hybrid thermoplastic composites (front-back face: $x 7$, cross-section: $x 10$ magnification)

both its surface and cross-section. The intra-ply/interply hybrid PP/IL1 composite showed the similar front face failure with PP/CC as an intense fiber undulation. The back face failure of PP/IL1 was also similar with $\mathrm{PP} / \mathrm{HC}$ as the fiber-matrix delamination. Matrix crack, fiber breakage and a layer delamination between PP/C and PP/H layer were also observed. The failure of inter-ply hybrid PP/IL2 composite on the front face was observed as fiber undulations while the back face had an insignificant failure as PP/GC composite. Fiber breakage and a local delamination were observed on the cross-sectional view. The intra-ply/inter-ply hybrid PP/IL3 composite showed a fewer fiber undulation on its front face compare to PP/IL1 and PP/IL2. Fiber-matrix delamination was observed on both its back face and cross-section. The cross-sectional view of PP/IL3 showed a 
catastrophic fiber breakage. It was found that the intra-ply hybridization caused a more catastrophic failure on both surface and cross-section than interply and intra-ply/inter-ply hybridization.

Figure 8 shows the surface and cross-sectional SEM failure analyses of hybrid thermoplastic composites. SEM analyses are compatible with optical microscope views. PP/CC showed a deep matrix crack and fiber/matrix delamination on its top face. Inter-ply delamination, intensive fiber breakages and localized kinking zone were observed on cross-sectional view. A fiber undulation, minor matrix crack and fiber/matrix delamination were observed on the front face of PP/GC. Some of the intra-ply and inter-ply delamination were occurred on the cross-sectional view of PP/GC. PP/HC showed a severe fiber/matrix delamination on its top face due to using both carbon and E-glass fiber in intra-ply hybridization. And also, extensive inter-ply/intra-ply delamination and fiber breakages were observed in the cross-sectional view of PP/HC. An intense fiber undulation, a deep matrix crack and multiple fiber breakages were occurred on

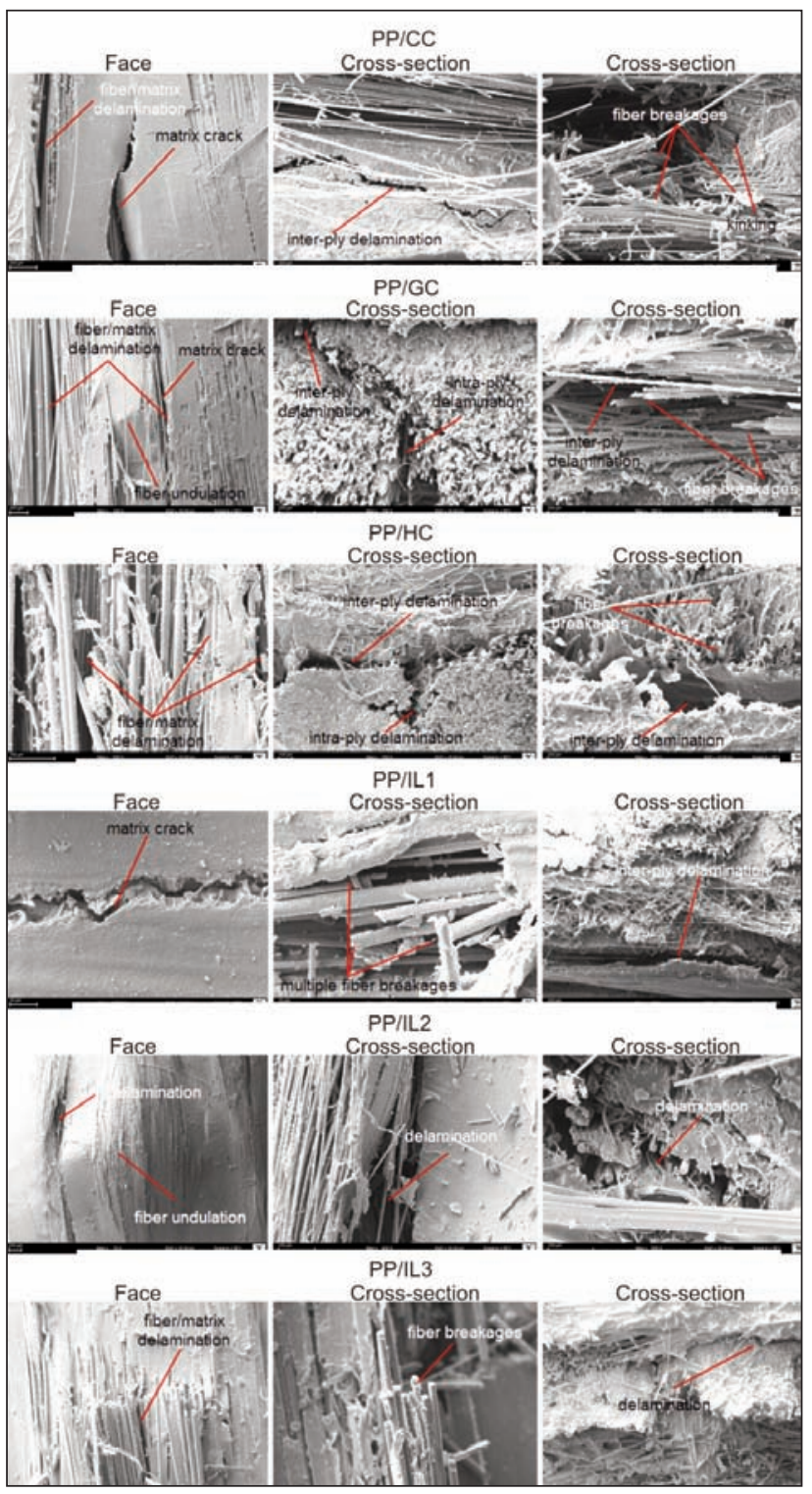

Fig. 8. The surface and cross-sectional SEM failure analyses of hybrid thermoplastic composites the top face of PP/IL1. The cross-sectional failure of PP/IL1 was observed as inter-ply delamination. The front face failure of PP/IL2 was observed as fiber undulations while fiber breakages and a local delamination were observed on the cross-sectional view. Fiber/matrix delamination and some fiber breakages were observed on the front face of PP/IL3. A catastrophic fiber breakage was observed on the crosssectional views of PP/IL3 while the inter-ply and intraply delamination was restricted due to the stronger fiber/matrix interface of E-glass/PP.

\section{CONCLUSIONS}

Bending properties of intra-ply, inter-ply and intraply/inter-ply Carbon/E-Glass/PP hybrid thermoplastic composites were compared with those of non-hybrid Carbon/PP and E-Glass/PP thermoplastic composites. The conclusions are:

- UD woven thermoplastic prepregs are suitable materials to achieve the desired hybridization related to load to be exposed and end-use areas of composites which provides design flexibility.

- The densities of hybrid thermoplastic composites were affected by the ratios of different fiber types used in hybridization. The composite density was increased by the increase in E-Glass fiber ratio. The lowest composite density was obtained from PP/CC since the lower density of carbon fiber compare to that of E-glass fiber. Fibre fractions can be varied by the constructional arrangements of weaving as using different warp and weft densities, weaving patterns and yarn linear densities.

- The carbon fibers are used for their high strength in hybridization. The glass fibers have higher strainto-failure in tension than that of carbon fibers which provides higher strength to hybrid composites. $\mathrm{PP} / \mathrm{CC}$ composites are generally stiffer than PP/GC and $\mathrm{PP} / \mathrm{HC}$ composites because of the brittle behavior of carbon fibers. PP/HC intra-ply hybrid composites are more flexible compared to nonhybrid composites since the contribution of higher strain of glass fibers.

- The bending-strength of hybrid thermoplastic composites was significantly improved by the intra-ply, inter-ply or intra-ply/inter-ply hybridization. The intra-ply/inter-ply hybridization (PP/IL1) increased the bending strength as $19.4 \%$ compared to nonhybrid composites. It could be caused by the constraint from the intra-ply and inter-ply E-glass fibers that prevent carbon fiber breakages and formed a considerable hybridization effect due to the delay in failure of the carbon fibers [39]. The uniform distribution of carbon and E-glass fibers within and between the layers the composite structure was also increased the bending strength of composites. Bending strength is mainly dependent on the fibercontent and fiber-properties of the composites which confirms the synergic effect of hybridization.

- The fiber fractions affected the bending-modulus of composites. The bending-modulus of hybrid com- 
posites generally increased by the increase in Carbon fiber fraction because of the higher fiber modulus of Carbon compared to E-Glass fiber. However, non-hybrid PP/CC showed low bending modulus because of the weak interface properties of carbon/PP during consolidation process.

- The intra-ply, inter-ply and intra-ply/inter-ply hybridizations increased the bending modulus of composites because of the combining the unique specific modulus of Carbon and strain of E-Glass fibres.

- The uniform distribution of Carbon and E-Glass fibers within and between the layers of composites by using intra-ply/inter-ply hybridization resulted as the higher bending modulus up to $65.1 \%$ compared to non-hybrid composites.

- The bending-deflection of hybrid thermoplastic composites was significantly affected by the intraply, inter-ply or intra-ply/inter-ply hybridization and fiber ratios used. The ductility of hybrid thermoplas- tic composites decreased by the increase in Carbon fiber ratio of the composite.

- The Carbon/PP and E-Glass/PP fibers showed different adhesion properties during consolidation process which caused by the different surface and heat-transfer properties of Carbon and E-Glass fibers. The non-hybrid and hybrid thermoplastic composites generally showed a layer delamination and fiber breakages on their cross-section and fiber undulations on their front faces. The intra-ply hybridization caused a more catastrophic failure on both surface and cross-section than those in interply and intra-ply/inter-ply hybridization.

- It is evaluated that using Carbon fiber at the top layer makes the hybrid thermoplastic composites stiff and increases the bending strength and modulus.

\section{ACKNOWLEDGEMENTS}

The author would like to thank Kahramanmaras Sutcu Imam University Scientific Research Unit, Turkey for supporting this study (2016/3-76 M).

\section{BIBLIOGRAPHY}

[1] Hoa, S. V. Principles of the manufacturing of composite materials, DEStech Publications, Inc., Lancaster, 2009, pp. 3-15.

[2] Offringa, A.R. Thermoplastic composites-rapid processing applications, In: Composites Part A: Applied Science and Manufacturing, 1996, vol. 27, pp. 329-336.

[3] Iyer, S.R., Drzal, L.T. Manufacture of powder-impregnated thermoplastic composites, In: Journal of Thermoplastic Composite Materials, 1990, vol. 3, pp. 325-355.

[4] Joncas, S., M. Sc. Dissertation, Thermoplastic composite wind turbine blades: An integrated design approach, Université du Québec, Canada, 2010.

[5] Brandrup, J., Immergut, H., Grulke, A. Polymer Handbook, 4th ed., John Willey \& Sons, Inc., New York, 1999, pp. 171-186.

[6] Mazumdar, S. K. Composites manufacturing, materials, product and process engineering, CRC Press, USA, 2002, pp. 45-60.

[7] Choi, B. D., Diestel, O., Offermann, P. Commingled CF/PEEK hybrid yarns for use in textile reinforced high performance rotors, 19th International Conference on Composite Materials (ICCM), Montreal, 2013.

[8] Thwe, M.M., Liao, K. Durability of bamboo-glass fiber reinforced polymer matrix hybrid composites, In: Composite Science Technology, 2003, vol. 63, pp. 375-387.

[9] Gupta, M. K., Srivastava, R. K., Mechanical properties of hybrid fibers reinforced polymer composite: A review, In: Polymer-Plastics Technology and Engineering, 2016, vol. 55, pp. 626-642.

[10] Pandya, K. S., Veerraju, Ch., Naik, N. K. Hybrid composites made of carbon and glass woven fabrics under quasistatic loading, In: Materials and Design, 2011, vol. 32, pp. 4094-4099

[11] Mallick, P. K. Fiber reinforced composites materials, manufacturing and design, CRC Press, USA, 2007, pp. 55-70.

[12] Mader, E., Rausch, J., Schmidt, N. Commingled yarns - processing aspects and tailored surfaces of polypropylene/glass composites, In: Composites Part A: Applied Science and Manufacturing, 2008, vol. 39, pp. 612-623.

[13] Long, A. C., Wilks, C. E., Rudd, C.D. Experimental characterization of the consolidation of a commingled glass/polypropylene composite, In: Composites Science and Technology, 2001, vol. 61, pp. 1591-1603.

[14] Alagirusamy, R., Fangueiro, R., Ogale, V., Padaki, N. Hybrid yarns and textile preforming for thermoplastic composites, In: Textile Progress, 2006, vol. 38, no. 4, pp. 1-71.

[15] Wakeman, M. D., Cain, T. A., Rudd, C. D., Brooks, R., Long, A.C. Compression moulding of glass and polypropylene composites for optimised macro and micro mechanical properties of commingled glass and polypropylene, In: Composites Science and Technology, 1998, vol. 58, pp. 1879-1898.

[16] Lariviere, D., Krawczak, P. Interfacial properties in commingled yarn thermoplastic composites, part i: characterization of the fiber/matrix adhesion, In: Polymer Composites, 2004, vol. 25, pp. 577-587.

[17] Ye, L., Friedrich, K., Kastel, J., Mai, Y.W. Consolidation of unidirectional CF/Peek composites from commingled yarn prepreg, In: Composites Science and Technology, 1995, vol. 54, pp. 349-358.

[18] Alagirusamy, R., Ogale, V. Commingled and air jet-textured hybrid yarns for thermoplastic composites, In: Journal of Industrial Textiles, 2004, vol. 33, no. 4, pp. 223-243.

[19] Schafer, J., Stolyarov, O., Ali, R., Greb, C., Seide, G., Gries, T. Process-structure relationship of carbon/polyphenylene sulfide commingled hybrid yarns used for thermoplastic composites, In: Journal of Industrial Textiles, 2016, vol. 45, no. 6, pp. 1661-1673. 
[20] Ishikawa, T., Chou, T. W. Elastic behavior of woven hybrid composites, In: Journal of Composite Materials, 1982 , vol. 16, pp. 2-19.

[21] Baghaei, B., Skrifvars, M., Berglin, L. Characterization of thermoplastic natural fibre composites made from woven hybrid yarn prepregs with different weave pattern, In: Composites Part A: Applied Science and Manufacturing, 2015, vol. 76, pp. 154-161.

[22] Baghaei, B., Skrifvars, M. Characterisation of polylactic acid biocomposites made from prepregs composed of woven polylactic acid/hemp-lyocell hybrid yarn fabrics, In: Composites Part A: Applied Science and Manufacturing, 2016, vol. 81, pp. 139-144.

[23] Dong, C., Davies, I. J. Flexural and tensile strengths of unidirectional hybrid epoxy composites reinforced by S-2 glass and T700s carbon fibres, In: Materials and Design, 2014, vol. 54, pp. 955-966.

[24] Khatria, S. C., Koczak, M. J. Thick-Section as 4-Graphite/E-Glass/PPS hybrid composites: Part II. Flexural response, In: Composites Science and Technology, 1996, vol. 56, no. 4, pp. 473-482.

[25] Sorrentino, L., Simeoli, G., lannace, S., Russo, P. Mechanical performance optimization through interface strength gradation in PP/Glass fiber reinforced composites, In: Composites Part B, 2015, vol. 76, pp. 201-208.

[26] Xu, Z., Zhang, M., Wang, G., Luan, J. Bending property and fracture behavior of continuous glass fiber-reinforced peek composites fabricated by the wrapped yarn method, In: High Performance Polymers, 2018, DOI: 10.1177/0954008318767500.

[27] Shekar, R. I., Kotresh, T. M., Krishna Prasad, A. S., Damodhara Rao, P. M., Satheesh Kumar, M. N., Siddaramaiah, Hybrid fiber fabric composites from poly ether ether ketone and glass fiber, In: Journal of Applied Polymer Science, 2010, vol. 117, pp. 1446-1459.

[28] Zhang, J., Chaisombat, K., He, S., Wang, C.H. Hybrid composite laminates reinforced with glass/carbon woven fabrics for lightweight load bearing structures, In: Materials and Design, 2012, vol. 36, pp. 75-80.

[29] Sreekala, M. S., George, J., Kumaran, M. G., Thomas, S. The mechanical performance of hybrid phenolformaldehyde-based composites reinforced with Glass and Oil Palm fibers, In: Composites Science and Technology, 2002, vol. 62, pp. 339-353.

[30] Sevkat, E., Liaw, B., Delale, F., Raju, B.B. Drop-weight impact of plain-woven hybrid glass-graphite/toughened epoxy composites, In: Composites Part A: Applied Science and Manufacturing, 2009, vol. 40, pp. 1090-1110.

[31] ISO 5084-1996 Determination of thickness of textiles and textile products, 1996

[32] ISO 7211-3-1984 Woven fabrics - construction - methods of analysis - Part 3: Determination of crimp of yarn in fabric, 1984.

[33] ISO 6348-2011 Determination of Mass - Vocabulary, 2011.

[34] ASTM D792-2013 Standard test methods for density and specific gravity (relative density) of plastics by displacement, 2013.

[35] ASTM D3171-2015 Standard test methods for constituent content of composite materials, 2015.

[36] ASTM D790-1990 Standard test methods for flexural properties of unreinforced and reinforced plastics and electrical insulating materials, 1990.

[37] Bilisik, K., Yolacan, G. Warp-weft directional bending properties of multistitched biaxial woven E-Glass/Polyester nano composites, In: Journal of Industrial Textiles, 2015, vol. 45, no. 1, pp. 66-100.

[38] Mukhopadhyay, S., Deopura, B. L., Alagiruswamy, R. Interface behavior in polypropylene composites, In: Journal of Thermoplastic Composite Materials, 2003, vol. 16, pp. 479-495.

[39] Wisnom, M.R., Czél, G., Swolfs, Y., Jalalvand, M., Gorbatikh, L., Verpoest, I. Hybrid effects in thin ply carbon/glass unidirectional laminates: Accurate experimental determination and prediction, In: Composites: Part A, 2016, vol. 88, pp. 131-139.

[40] Bilisik, K., Ozdemir, H., Yolacan Kaya, G. Interlaminar shear strength properties of multistitched preform nano composites, In: Industria Textila, 2016, vol. 67, no. 2, pp. 127-131.

[41] Spragg, C. J., Drzal, L. T., Fiber, matrix, and interface properties, ASTM, 1996, USA, pp. 168-180.

\section{Authors:}

\section{GAYE YOLACAN KAYA}

Department of Textile Engineering, Faculty of Engineering and Architecture

Kahramanmaras Sutcu Imam University

46040 Kahramanmaras, Turkey

Corresponding author:

GAYE YOLACAN KAYA

e-mail: gkaya@ksu.edu.tr 